\title{
Extracellular phosphoesterases of invertebrate origin: underrated actors in phosphorus recycling?
}

\author{
Imke Maiken Böök ${ }^{1,2} \cdot$ Reinhard Saborowski $^{1}$ (D)
}

Received: 23 May 2019 / Accepted: 24 January 2020 / Published online: 3 March 2020

(c) The Author(s) 2020

\begin{abstract}
Extracellular enzymes contribute substantially to the remineralisation of organic matter in aquatic systems. Marine invertebrates release endogenous enzymes through activities such as sloppy feeding or egestion, but the significance of such processes is widely unexplored. We compared functional key properties such as activity, stability, and apparent molecular masses of extracellular phosphatases from faeces of the marine crustaceans Idotea balthica, Palaemon varians, and Homarus gammarus with those of their digestive organs. A fluorescent substrate was used to examine enzyme activity qualitatively on agarose plates and quantitatively in microplate assays. Apparent molecular masses and enzyme stability were examined by native substrate gel electrophoresis (NSGE). Active extracellular phosphatase were present in the faeces of all tested species. NSGE activity band patterns were similar in digestive tissue extracts and faeces extracts. The initial enzyme activity retained for about 2 days, but thereafter rapidly decreased. Activity band patterns of digestive organs and faeces of I. balthica remained consistent for up to $72 \mathrm{~h}$. Antibiotic treatment did not reduce phosphatase activity in the faeces of I. balthica and $H$. gammarus but in the faeces $P$. varians. Because of the comparatively high activities in the faeces, the electrophoretic similarity between faeces and digestive organs, and the limited durability of the enzymes in faeces extracts, we conclude that the studied crustaceans release predominantly endogenous, rather than bacterial phosphatases through faeces. These can substantially contribute to the pool of active extracellular phosphatases and the recycling of phosphorus in aquatic systems. The wider physiological and ecological context is discussed.
\end{abstract}

\section{Introduction}

Phosphorus is an essential element for all life on earth. It fulfils many functions such as energy storage (ATP), structuring of cells (phospholipids in cell membranes), and the

Responsible Editor: M. Huettel.

Reviewed by C. Davis and an undisclosed expert.

Electronic supplementary material The online version of this article (https://doi.org/10.1007/s00227-020-3654-6) contains supplementary material, which is available to authorized users.

Reinhard Saborowski

Reinhard.Saborowski@awi.de

1 Alfred Wegener Institute, Helmholtz Centre for Polar and Marine Research, Am Handelshafen 12, 27570 Bremerhaven, Germany

2 Present Address: Victoria University Coastal Ecology Laboratory and School of Biological Sciences, Victoria University of Wellington, P.O. Box 600, Wellington, New Zealand formation of DNA (Paytan and McLaughlin 2007; White and Dyhrman 2013). Continental weathering and transport via rivers (fluvial) and air (aeolian) is the primary import of phosphorus to the oceans (Föllmi 1996). Biologically bound phosphorus is released as particulate or dissolved inorganic and organic phosphorus (Johannes 1964; Hargrave and Geen 1968). While the inorganic phosphorus compounds can be readily assimilated and incorporated by biota, the organic compounds need to be degraded first. Many organisms possess phosphoester hydrolases (phosphatases) that can hydrolyze organic phosphorus compounds and generate inorganic phosphorus (Clark et al. 1998; Štrojsová et al. 2003; Dyhrman and Ruttenberg 2006). The enzymatic degradation of organic phosphorus through alkaline phosphatase is regarded as the most important process for the remineralisation of dissolved organic phosphorus (Suzumura et al. 2012 and references therein).

Extracellular enzymes play important roles in aquatic nutrient cycles, as they are essential drivers of remineralisation processes (Baltar et al. 2010; Arnosti 2011). Dissolved enzymes contribute significantly to the pool of total enzyme 
activities in marine environments (Karner and Rassoulzadegan 1995; Pantoja and Lee 1999). Extracellular enzymes in marine systems comprise, among others, proteases, glucosidases, chitinases, lipases, and phosphatases (Hoppe 1983; Hoppe et al. 2002). Bacteria are able to express these enzymes and release them into the water (Martinez et al. 1996). In addition to the extracellular enzymes released by bacteria, Karner et al. (1994) and Bochdansky et al. (1995) showed that extracellular enzyme activity can be provided by phagotrophic nanoflagellates and copepod grazing activities (e.g., sloppy feeding).

It has been suggested, that marine invertebrates might release extracellular enzymes through major physiological processes such as excretion and moulting (Boavida and Heath 1984; Espie and Roff 1995; Oosterhuis et al. 2000). However, studies that focus on the enzymatic activity released through these processes are scarce and little is known about enzyme properties and their possible contribution to marine nutrient cycles.

The aim of the present study was to investigate the extracellular enzyme activity in the faeces of marine invertebrates, particularly crustaceans, and to examine whether these enzymes are of endogenous origin through comparison with activities of the digestive organs. Three crustacean species, the isopod Idotea balthica (Peracarida) and two decapod species, the shrimp, Palaemon varians, and the lobster, Homarus gammarus, were chosen for this study. The fluorogenic substrate 4-methylumbelliferyl phosphate (MUF-P) was used to investigate the activities of phosphatase enzymes by complementary biochemical methods: agarose-substrate plates were used to visualise enzymes liberated from the samples, microplate assays were conducted to quantify enzyme activities, and zymograms were prepared to compare the apparent molecular masses of activity band patterns. Phosphatase activity in faeces was also measured in antibiotic-treated samples to estimate the potential enzyme sources (bacterial vs. crustacean) and their relative contribution to the activities of species. Additionally, the stability of phosphatase enzymes from faeces was investigated. The following hypotheses were tested: (1) marine crustaceans release extracellular phosphatases through faeces.
(2) These phosphatases are of endogenous origin. (3) The phosphatases are stable under natural conditions and, thus, capable of contributing to marine nutrient cycling.

\section{Materials and methods}

\section{Origin of animals}

Marine isopods, Idotea balthica, were taken from an established mass culture at the Alfred-Wegener Institute (AWI) in Bremerhaven. The animals were maintained in a 50-L flowthrough aquarium in natural seawater of $15 \pm 1{ }^{\circ} \mathrm{C}$ and $30 \pm 2$ salinity. Twice a week, animals were fed with fresh bladder wrack, Fucus vesiculosus.

Atlantic ditch shrimps, Palaemon varians, were collected during summer with a hand-net from an urban pond in Bremerhaven (Holzhafen, 53 32' 08.4" N 8 35' 29.0" E). The animals were maintained in $10-\mathrm{L}$ aquaria at $15 \pm 1{ }^{\circ} \mathrm{C}$ and $15 \pm 0.3$ salinity. Animals were fed with commercial fish feed every other day (NovoVert, Neuhofen, Germany) and with freshly hatched Artemia nauplii (Great Salt Lake Artemia Cysts, Sanders, USA) once a week. The water was always exchanged the day after feeding.

Juvenile European lobsters, Homarus gammarus, (about $4 \mathrm{~cm}$ total length), were provided by the Lobster Rearing Facility at Helgoland (Dr. Isabel Schmalenbach). Upon arrival in Bremerhaven, the animals were kept separately in rectangular $10 \times 10 \mathrm{~cm}$ compartments within a $40 \times 25 \times 20 \mathrm{~cm}$ flow through aquarium supplied with natural seawater. The temperature was $15 \pm 1{ }^{\circ} \mathrm{C}$ and the salinity $30 \pm 2$. The animals were fed with frozen shrimps (abdominal muscle) twice a week. Pieces of Fucus vesiculosus, were also added, providing additional food and shelter.

\section{Sample collection, dissection, and processing}

A set of different analysis was carried out with samples of faeces and digestive organs of the three crustacean species (Table 1).
Table 1 Overview of methods and treatments applied (X) to species and sample type

\begin{tabular}{|c|c|c|c|c|c|c|}
\hline \multirow{2}{*}{$\begin{array}{l}\text { Species } \\
\text { Sample }\end{array}$} & \multicolumn{2}{|c|}{ Idothea balthica } & \multicolumn{2}{|c|}{ Palaemon varians } & \multicolumn{2}{|c|}{$\begin{array}{l}\text { Homarus gam- } \\
\text { marus }\end{array}$} \\
\hline & Faeces & Tissue & Faeces & Tissue & Faeces & Tissue \\
\hline Substrate agarose plates & $X$ & & $X$ & & $X$ & \\
\hline Phosphatase activity & $X$ & $X$ & $X$ & $\mathrm{X}$ & $X$ & $\mathrm{X}$ \\
\hline Antibiotic/antimycotic treatments & $X$ & & $\mathrm{X}$ & & $\mathrm{X}$ & \\
\hline Native substrate gel electrophoresis & $X$ & $X$ & $X$ & $X$ & $X$ & $X$ \\
\hline Stability of enzyme activity & $\mathrm{X}$ & & $\mathrm{X}$ & & $\mathrm{X}$ & \\
\hline Stability of activity band patterns & $X$ & $\mathrm{X}$ & & & & \\
\hline
\end{tabular}




\section{Faeces}

The isopods, Idotea balthica, were maintained in plastic containers with $500 \mathrm{~mL}$ seawater at $16{ }^{\circ} \mathrm{C}$ prior to faeces collection. The animals were either kept individually (samples for activity measurements) or in groups of six per container (samples for gel electrophoresis, agar plates, and stability measurements). The animals were fed with $F$. vesiculosus for at least $4 \mathrm{~h}$. The algae were removed, and the water of the container was exchanged with fresh seawater. Care was taken to remove food remains or already produced faecal pellets. Faeces were collected after $16 \mathrm{~h}$ of incubation.

The shrimps, $P$. varians, were also kept at $16{ }^{\circ} \mathrm{C}$. They were fed with fish feed, that they usually consumed within $30 \mathrm{~min}$. Therefore, the feeding time was reduced to one hour. After feeding, up to six shrimps were placed together in one 500-mL glass beaker filled with brackish water (salinity 15). To prevent coprophagia, a plastic grid with a mesh width of $5 \times 5 \mathrm{~mm}$ was fixed about $2 \mathrm{~cm}$ above the bottom of the beaker. After $16 \mathrm{~h}$, the faecal pellets were collected from the bottom of the beakers and prepared for further analysis.

The lobsters, H. gammarus, were not fed for three to four days before faecal pellet collection. On the day of collection, they were fed for at least $4 \mathrm{~h}$ with shrimps (abdominal muscle) and algae. The lobsters were placed separately in 1-L glass beakers, which were filled with natural filtered seawater. A grid was placed about $2 \mathrm{~cm}$ above the bottom. A small plastic halfpipe was inserted to provide shelter. After $16 \mathrm{~h}$, the produced faecal pellets were removed from the beakers and stored on ice. In all experiments, the light/dark cycle was $16: 8 \mathrm{~h}$.

The faeces were transferred into weighed $1.5-\mathrm{mL}$ reaction cups and allowed to settle for about $5 \mathrm{~min}$. Excess water was removed with a pipette. If needed, faeces were pulse-centrifuged for a maximum of $1 \mathrm{~min}$ to accelerate pelleting. The wet weight of the faeces was determined with a high precision scale (RC 210S MC1, Sartorius AG, Göttingen, Germany).

Samples assigned for enzyme activity measurements were suspended in ten parts $(\mathrm{w} / \mathrm{v})$ of ultrapure water (Milli-Q), homogenised for two minutes with a micro pestle, and centrifuged for $10 \mathrm{~min}$ at $25,000 \mathrm{~g}$ and $4{ }^{\circ} \mathrm{C}$. The supernatants were used for further analysis.

Faecal pellet samples assigned for gel electrophoresis were suspended in 20 to $30 \mu \mathrm{L}$ of diluted (1:2) sample buffer $\left(0.375 \mathrm{~mol} \mathrm{~L}^{-1}\right.$ Tris/HCl, $\mathrm{pH} 8.8,30 \%$ (v/v) glycerol, $4 \%$ (w/v) SDS, $0.2 \mathrm{mg} \mathrm{mL}^{-1}$ bromophenol blue) and then homogenised and centrifuged as described before. The supernatants were directly loaded into the gel pockets. In between processing steps, samples were stored on ice.

\section{Digestive organs}

Digestive organs were used for enzyme activity measurements and gel electrophoresis. Prior to dissection, the animals were placed in a freezer $\left(-80^{\circ} \mathrm{C}\right)$ for 2 min to sedate them. Midgut glands, also referred to as hepatopancreas, were dissected from $P$. varians and $H$. gammarus. The digestive organs dissected from I. balthica included the midgut gland and the gut. Samples were extracted in ten parts (w/v) of ultrapure water (Milli-Q, Merck, Darmstadt, Germany), homogenised for 2 min with a micro pestle, and centrifuged for $10 \mathrm{~min}$ at $25,000 \mathrm{~g}$ and $4{ }^{\circ} \mathrm{C}$. Samples used for gel electrophoresis were diluted (1:2) with sample buffer (see 2.8) and directly loaded into the gel pockets.

\section{Phosphoesterase assays}

4-Methylumbelliferyl (MUF) derivatives provide a sensitive tool for enzyme activity detection. They have been used to measure enzymatic activity in water samples or small organisms (e.g., Hoppe 1993; Oosterhuis et al. 2000, Prim et al. 2003, Knotz et al. 2006). Here, we further refined this method to detect phosphoesterase activity the substrate 4-methylumbelliferyl phosphate (MUF-P, Sigma M8883) after electrophoretic separation in digestive organs and, particularly, the faeces of three crustacean species.

\section{Visualisation of faecal pellet phosphatase activity on substrate agarose plates}

Agarose plates were prepared with $1 \%$ agarose and $0.1 \mathrm{mmol} \mathrm{L}^{-1}$ of the substrate MUF-P. The substrate was dissolved in dimethyl sulfoxide (DMSO, Sigma 34569). Agarose was mixed with either sterile filtered seawater (salinity 30 for H. gammarus and I. balthica) or sterile filtered brackish water (salinity 15 for $P$. varians) and heated in a water bath $\left(>95{ }^{\circ} \mathrm{C}\right)$ until the agarose was completely dissolved. The agarose solution was cooled down to about $45{ }^{\circ} \mathrm{C}$ and mixed with the substrate/DMSO solution. The final DMSO concentration was $2 \%$. After sufficient agitation, the agar was poured onto a petri dish $(9.3 \mathrm{~cm}$ diameter, $0.7 \mathrm{~cm}$ height). The agar was left to polymerize for 5-10 min before faecal pellets were placed on the agar surface. Excess water was removed with a pipette. The plate was incubated for $10 \mathrm{~min}$ in the dark. Photographs of the agar plate were made with the Gel Doc ${ }^{\mathrm{TM}}$ XR and Gel Documentation System (Bio Rad Laboratories, Hercules, California, USA).

\section{Enzyme assays}

Phosphatase activity measurements were conducted with the Fluoroskan FL Microplate reader at $355 \mathrm{~nm}$ (ex.) and $460 \mathrm{~nm}$ (em.). The fluorescence was measured every $30 \mathrm{~s}$ for 
$20 \mathrm{~min}$. The increase of the relative fluorescence per minute $\left(\mathrm{RFU} \cdot \mathrm{min}^{-1}\right.$ ) was the measure of enzyme activity. The activity was expressed as nmol. $\mathrm{min}^{-1} \cdot \mathrm{g}^{-1}$. For the sake of legibility, this was further defined as $\mathrm{mU} \cdot \mathrm{g}^{-1}\left(1 \mathrm{U}=\mu \mathrm{mol} \cdot \mathrm{min}^{-1}\right.$; $\mathrm{nmol} \cdot \mathrm{min}^{-1}=1 \mathrm{mU}$ ) throughout the study. A linear standard curve was prepared with $0-10 \mu \mathrm{mol} \cdot \mathrm{L}^{-1}$ of 4-methylumbelliferone (Sigma M1381). The buffer used for the enzyme assays was prepared with sterile filtered seawater (HEPESSW buffer) for I. balthica and H. gammarus, or with sterile filtered brackish water (HEPES-BW buffer) for $P$. varians. Preceding studies on enzyme assays and conditions are presented in the Supporting information.

\section{Phosphatase activity measurements}

Phosphatase activity was measured in faeces extracts from five different specimens of I. balthica and H. gammarus and from five different incubation experiments of $P$. varians. Faecal pellets of a single $P$. varians were not sufficient to run a standard assay. Therefore, for each sample of $P$. varians, faeces of six animals were pooled and extracted. Additionally, phosphatase activity was measured in digestive tissue extracts from five different animals per species. MUF-P was used as substrate. Extracts $(20 \mu \mathrm{L})$ were pipetted in triplicate into 96-well plates and mixed with $250 \mu \mathrm{L}$ of buffer-substrate solution (2\% DMSO, HEPES-SW buffer $\mathrm{pH}$ 8.2, MUF-P-substrate). The final substrate concentration was $0.1 \mathrm{mmol} \cdot \mathrm{L}^{-1}$.

\section{Enzyme activities in antibiotic/antimycotic-treated samples}

To test whether antibiotic/antimycotic treatment influence the enzyme activity in faeces, animals were incubated in antibiotic-treated seawater according to Donachie et al. (1995). Therefore, the antibiotics Ampicillin trihydrate (500 mg. ${ }^{-1}$; A-6140-25, Sigma) and Streptomycin sulfate $\left(250 \mathrm{mg} \cdot \mathrm{L}^{-1} ; 35500\right.$, Serva $)$, as well as the antimycotic Nystatin $\left(20 \mathrm{mg} \cdot \mathrm{L}^{-1}\right.$; J62486, Alfa Aesar (Thermo Fisher $\mathrm{GmbH}$ ) were dissolved in sterile filtered seawater and sterile filtered brackish water, respectively. The animals were allowed to feed in the treated water for up to $5 \mathrm{~h}$. Thereafter, they were transferred into clean antibiotic/antimycotictreated water and kept there for $16 \mathrm{~h}$.

\section{Native substrate gel electrophoresis}

Enzymes were separated by native sodium dodecyl sulfate polyacrylamide gel electrophoresis (SDS-PAGE). The gels were loaded with $10 \mu \mathrm{L}$ of extracts of faeces or digestive tissue, which were mixed with the bromophenol blue sample buffer. The extracts were neither treated with mercaptoethanol nor heated to avoid degradation of the enzymes. Gel electrophoresis was run at $300 \mathrm{~V}$ and $15 \mathrm{~mA}$ $(2$ gels $=30 \mathrm{~mA})$ in a SE 260 Mini-Vertical unit and an EPS 301 power supply (GE Healthcare, Chicago, Illinois, USA) until the migration front (bromophenol blue) reached the bottom of the gel $(\sim 1 \mathrm{~h})$. Subsequently, the gel was washed for $30 \mathrm{~min}$ in demineralised water and incubated for $30 \mathrm{~min}$ in $0.1 \mathrm{mmol} \cdot \mathrm{L}^{-1} \mathrm{MUF}-\mathrm{P}$ substrate solution. If a non-fluorescent molecular weight marker was used, the gels were additionally stained overnight in a solution of Coomassie Brilliant Blue. Gels were photographed with a Gel Doc ${ }^{\mathrm{TM}} \mathrm{EZ}$ device. The fluorescence of the gel pictures was presented using the colour scale "spectrum" (Image Lab software). The molecular mass of the bands was calculated using the relative migration distance $\left(R_{\mathrm{f}}=\right.$ retardation factor $)$.

\section{Stability measurements}

\section{Enzyme activities}

The determination of enzyme stability demanded high amounts of faecal pellets. Therefore, isopod and shrimp faeces were collected from six separate incubations in 1-L glass beakers, each containing six I. balthica and six P. varians, respectively. The faeces of either species were pooled to obtain three replicates. Three samples of lobster faeces from six individuals were also collected. The samples were homogenised in $400-450 \mu \mathrm{L}$ sterile filtered natural seawater or brackish water, respectively. The enzyme activities were measured immediately after the extracts were prepared $\left(T_{0}\right)$ and then again after 4, 24, 48, 96 and $192 \mathrm{~h}$. In between, the samples were stored in the dark at $16^{\circ} \mathrm{C}$. The assays and the measurements were conducted as described before.

\section{Activity band patterns}

To investigate whether aged faeces showed changes in the activity band patterns, extracts were incubated for up to $72 \mathrm{~h}$. Samples taken at different incubation times were subjected to native electrophoresis. For the time series, 5-6 I. balthica were placed in a single container ( 25 containers total) and left to feed for $4 \mathrm{~h}$. Thereafter, animals from each container were transferred into new containers with fresh seawater and left to egest for $2 \mathrm{~h}$. Next, the animals were separated from the faeces produced during the $2 \mathrm{~h}$ of egestion. The faeces remained in the containers at $16{ }^{\circ} \mathrm{C}$ in the dark and samples were taken after $2,12,24,48$ and $72 \mathrm{~h}$. The samples were stored at $-80{ }^{\circ} \mathrm{C}$ until electrophoresis. Digestive organs were dissected, transferred into reaction tubes, and incubated for up to $72 \mathrm{~h}$ at $16{ }^{\circ} \mathrm{C}$. Extracts were prepared as described before and mixed with $20-30 \mu \mathrm{L}$ of sample buffer. Electrophoresis was carried out as described before. 


\section{Statistics}

The raw data were assembled for analysis with Excel (Microsoft Corporation, Washington, USA). Statistical analyses were conducted with R-studio (RStudio Inc., Boston, USA). Graphs were prepared using the ggplot package of R-studio.

The homogeneity of variance of data sets was tested with the Bartlett's test and normal distribution with the Shapiro-Wilkinson test. If data were not normally distributed and/or lacked variance homogeneity, the non-parametric Kruskal-Wallis test was used to test for significant differences within data sets. For the post hoc pairwise comparisons (Dunn's Test) of phosphatase activity between species, the Benjamini-Hochberg correction was used to adjust the $p$ values and the $H_{0}$ hypothesis was rejected if $p \leq \alpha / 2$. To identify significant differences between the antibiotic-treated samples and the untreated samples, the Student's $t$ Test was applied whenever data were normally distributed, and variances were equal. Otherwise, the Mann-Whitney $U$ test was applied.

The time series was conducted with three replicates for faeces extracts of each species. First, the highest activity of any time-point of each replicate was set to $100 \%$. The other activities were calculated in relation to the highest value (\%). to calculate the time-point where $50 \%$ of the initial enzyme activity remained (similar to effective dose values $\mathrm{ED}_{50}$ ) and to display enzyme stability over time, a dose response model based on the Boltzmann function was applied:

$f(x)=a+\frac{b}{1+\mathrm{e}^{\frac{x-m}{s}}}$

The dose response models were calculated with the "drm" function from the package "drc v2.2-12". The " $\mathrm{ED}_{50}$ " values were calculated with the "drc v3.01" from the same package. ( $a=$ minimum of the fit, $b=$ maximum of the fit, $m=$ point of inflection, $50 \%$ level of the function, $s=$ slope at the point of inflection).

\section{Results}

\section{Visualisation of phosphatase activity on substrate-agarose plates}

Faecal pellets collected from I. balthica and placed on the seawater MUF-P agar yielded a strong fluorescence around the pellets (Fig. 1a, b). The faecal pellets of $P$. varians produced a faint but also clearly visible fluorescent signal on the agar substrate plate prepared with brackish water (Fig. 1c, d). The faecal pellets of $H$. gammarus produced an intensive fluorescent signal on the seawater MUF-P agar (Fig. 1e, f).

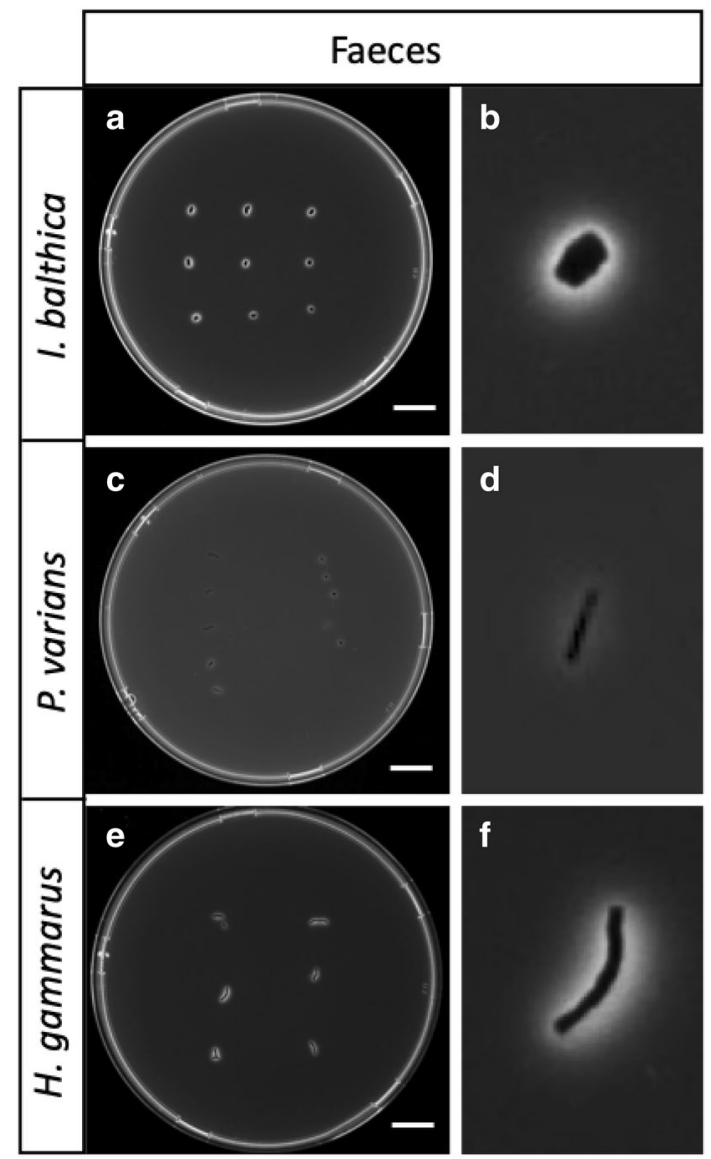

Fig. 1 Visualisation of phosphatase activity diffusing from faeces of the three crustacean species Idotea balthica $(\mathbf{a}, \mathbf{b})$ Palaemon varians (c, d), and Homarus gammarus (e, f). The white scale bar indicates a width of $10 \mathrm{~mm}$. Pictures on the right without scale are not zoomed in but electronically enlarged

\section{Phosphatase activity measurements}

Phosphatase activities in digestive tissue extracts of $I$. balthica varied strongly between specimens. Average activity was $1816 \pm 260 \mathrm{mU} \cdot \mathrm{g}^{-1}$. The maximum activity was $2266 \mathrm{mU} \cdot \mathrm{g}^{-1}$ and the minimum activity was $1594 \mathrm{mU} \cdot \mathrm{g}^{-1}$ (Fig. 2a). The phosphatase activities in digestive tissue extracts of $P$. varians also differed between samples. It varied between 577 and $2431 \mathrm{mU} \cdot \mathrm{g}^{-1}$. The mean activity was $1268 \pm 755 \mathrm{mU} \cdot \mathrm{g}^{-1}$ (Fig. 2b). The average phosphatase activity in the digestive tissue extracts of $\mathrm{H}$. $\mathrm{gam}$ marus was $226 \pm 158 \mathrm{mU} \cdot \mathrm{g}^{-1}$. The lowest activity detected was $125 \mathrm{mU} \cdot \mathrm{g}^{-1}$ and the highest activity was $408 \mathrm{mU} \cdot \mathrm{g}^{-1}$ (Fig. 2c).

The average phosphatase activity in faeces of I. balthica was $47.0 \pm 21.9 \mathrm{mU} \cdot \mathrm{g}^{-1}$. The maximum activity was $79.2 \mathrm{mU} \cdot \mathrm{g}^{-1}$ and the minimum activity was $24.4 \mathrm{mU} \cdot \mathrm{g}^{-1}$ (Fig. 2d). The phosphatase activity in the faeces represented about $2.5 \%$ of the phosphatase activity in the 
Fig. 2 Boxplots showing phosphatase activity in digestive tissues $(\mathbf{a}-\mathbf{c})$, faeces $(\mathbf{d}-\mathbf{f})$, and faeces ( $(\mathbf{g}-\mathbf{i})$ after antibiotic/ antimycotic treatment of Idotea balthica, Palaemon varians and Homarus gammarus $(n=5)$

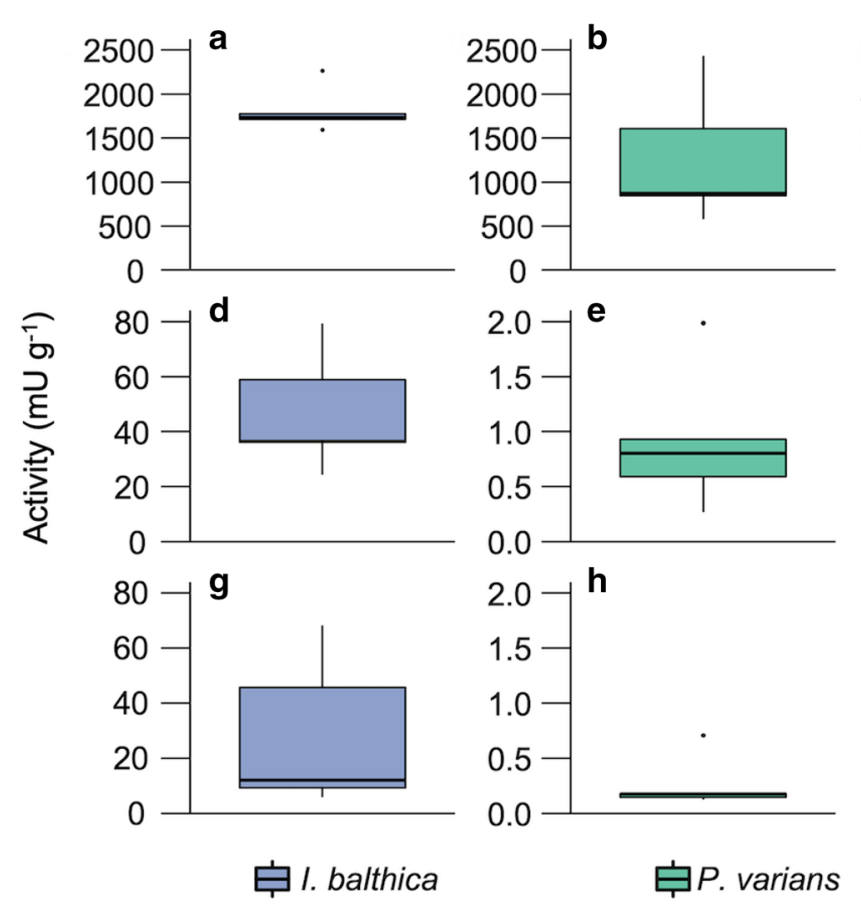

digestive tissue of $I$. balthica. Phosphatase activity in faeces extracts of $P$. varians also differed between samples (faeces of six animals were pooled for analysis). The activities varied between 0.27 and $1.99 \mathrm{mU} \cdot \mathrm{g}^{-1}$. The calculated mean activity was $0.92 \pm 0.65 \mathrm{mU} \cdot \mathrm{g}^{-1}$ (Fig. 2e). The average phosphatase activity still present in the faeces made up $0.07 \%$ of the phosphatase activity in the digestive tissue of $P$. varians. The average phosphatase activity in faeces extracts of $H$. gammarus was $15.2 \pm 16.0 \mathrm{mU} \cdot \mathrm{g}^{-1}$. Here, activities also varied between specimens. The lowest activity detected was $4.4 \mathrm{mU} \cdot \mathrm{g}^{-1}$ and the highest activity was $42.9 \mathrm{mU} \cdot \mathrm{g}^{-1}$ (Fig. 2f). The average phosphatase activity still present in the faeces made up $6.7 \%$ of the phosphatase activity in the digestive tissue of $H$. gammarus.

\section{Statistical analysis of enzyme activity measurements}

Phosphatase activity in digestive tissue extracts was significantly different between I. balthica and H. gammarus $(p=0.009)$ but not between I. balthica and P. varians $(p=0.145)$ or $P$. varians and H. gammarus $(p=0.051)$.

Statistical analysis revealed a significant difference between the phosphatase activity in faeces extracts of $I$. balthica and $H$. gammarus $(p=0.001)$ but not between $P$. varians and $H$. gammarus $(p=0.036)$ and between $I$. balthica and P. varians $(p=0.089)$.

\section{Enzyme activities in faeces after antibiotic/ antimycotic treatment}

Average phosphatase activity in faeces extracts of antibiotic/antimycotic-treated I. balthica was $28.3 \pm 0.9 \mathrm{mU} \cdot \mathrm{g}^{-1}$. Maximum activity was $68.3 \mathrm{mU} \cdot \mathrm{g}^{-1}$ and minimum activity was $5.8 \mathrm{mU} \cdot \mathrm{g}^{-1}$ (Fig. $2 \mathrm{~g}$ ). Phosphatase activities in faeces extracts of antibiotic/antimycotic-treated $P$. varians also differed between samples (faeces of six animals were pooled for analysis). It varied between 0.12 and $0.71 \mathrm{mU} \cdot \mathrm{g}^{-1}$. The mean activity was $0.27 \pm 0.25 \mathrm{U}$ (Fig. $2 \mathrm{~h}$ ). Average phosphatase activities in faeces of antibiotic/antimycotic-treated H. gammarus was $22.1 \pm 15.1 \mathrm{mU} \cdot \mathrm{g}^{-1}$. Lowest activity was $5.4 \mathrm{mU} \cdot \mathrm{g}^{-1}$ and highest activity was $43.2 \mathrm{mU} \cdot \mathrm{g}^{-1}$ (Fig. 2i).

\section{Statistical analysis of enzyme activities after antibiotic treatment}

Phosphatase activities in faeces extracts of I. balthica were on average lower $\left(28.3 \mathrm{mU} \cdot \mathrm{g}^{-1}\right)$ after antibiotic/antimycotictreatment than in untreated samples $\left(47.0 \mathrm{mU} \cdot \mathrm{g}^{-1}\right)$. Statistical analysis indicated that the phosphatase activity of the two groups was not significantly different $(p=0.27)$.

The comparison of phosphatase activities in untreated and antibiotic/antimycotic-treated faeces of $P$. varians showed a higher mean phosphatase activity in the untreated samples $\left(0.92 \mathrm{mU} \cdot \mathrm{g}^{-1}\right)$ than in faeces after antibiotic treatment $\left(0.27 \mathrm{mU} \cdot \mathrm{g}^{-1}\right)$. Statistical tests indicated that the 
phosphatase activities of the two groups were significantly different $(p=0.03)$.

The mean phosphatase activity in faeces of $H$. gammarus was higher in the antibiotic treated faeces $\left(22.1 \mathrm{mU} \cdot \mathrm{g}^{-1}\right)$ than in untreated samples $\left(15.2 \mathrm{mU} \cdot \mathrm{g}^{-1}\right)$. Statistical analysis showed no significant differences between the two groups $(p=0.51)$.

\section{Native substrate gel electrophoresis}

The gels stained with MUF-phosphate displayed an activity band of apparently $56 \mathrm{kDa}$ in digestive tissue and faeces extracts of I. balthica. Additionally, a band of $34 \mathrm{kDa}$ appeared in all three extracts (Fig. 3a). Comparison of $P$. varians faeces extracts $(F)$ with digestive tissue (DT) extracts resulted in activity bands at $125 \mathrm{kDa}, 40 \mathrm{kDa}$ and $33 \mathrm{kDa}$, which were visible in extracts of both DT and F (Fig. 3b). Faeces extracts $(F)$ and digestive tissue extracts (DT) of $H$. gammarus revealed the same activity band at 46 kDa (Fig. 3c).

\section{Stability of enzymes}

The phosphatase activity in faeces extracts of $I$. balthica remained at initial high levels for $48 \mathrm{~h}$ but declined sharply thereafter. After 192 h, only about $4 \%$ of maximum activity remained. The $\mathrm{ED}_{50}$ was $91.6 \mathrm{~h}$ (3.8 days) (Fig. 4a). The phosphatase activity in faeces extracts of $P$. varians showed initial high values for $24 \mathrm{~h}$, and thereafter a strong decline. The calculated $\mathrm{ED}_{50}$ was $50.3 \mathrm{~h}$ (2.1 days). After $96 \mathrm{~h}$, no enzyme activity remained (Fig. 4b). The phosphatase activity in faeces extracts of $H$. gammarus decreased continuously from the beginning. The calculated $\mathrm{ED}_{50}$ was $64.2 \mathrm{~h}$ (2.7 days). After $192 \mathrm{~h}$, enzyme activity was $14.5 \pm 10.3 \%$ of the highest activity (Fig. 4c).

Fig. 3 Zymograms of phosphatases stained with MUF-P. a Idotea balthica; b Palaemon varians, and c Homarus gammarus. Extracts of digestive tissues (DT), faeces $(F)$, and the alga Fucus vesiculosus (FV). The apparent molecular weights in $\mathrm{kDa}$ are indicated on the left side of each panel

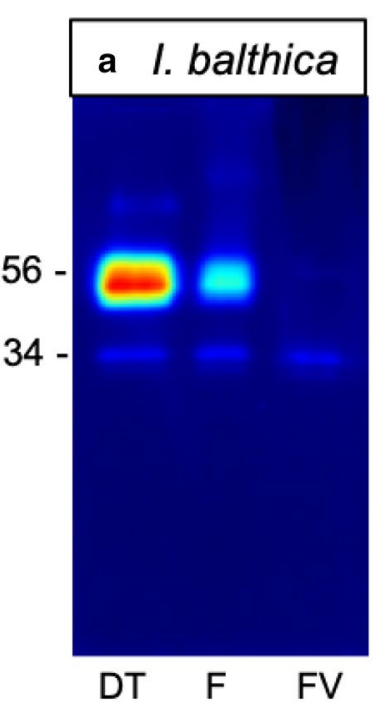

The stability time series conducted with digestive tissue extracts (Fig. 5a) and faeces extracts (Fig. 5b) of I. balthica showed the same band pattern from 2 to $72 \mathrm{~h}$ of incubation. Intensities of activity bands in digestive tissue extracts remained high until the end of the experiment (Fig. 5a). The intensity of the fluorescent signal of the faeces decreased after $12 \mathrm{~h}$. A faint activity remained until the end of the incubation after $72 \mathrm{~h}$ (Fig. 5b).

\section{Discussion}

Marked phosphatase activity was present in the faeces of the isopods and the two decapod species. Though microorganisms, e.g., bacteria, are omnipresent in nature and exude their enzymes, our study provides strong indications that the phosphatase in crustacean faeces are primarily of endogenous, i.e., crustacean, origin.

\section{Functional properties}

Phosphoesterases (phosphatases) are defined by their catalytic activity and certain structural and molecular properties like the active centre and specific domains (e.g., Millán 2006). Their molecular mass and their isoform pattern may however vary between taxa and, thus, can serve as a distinctive feature between crustacean and bacterial phosphatases.

The phosphatase activity bands visible in digestive tissue extracts of all three species were also present in the faeces extracts. This supports the hypothesis that the phosphatases found in the faeces are consistent with the digestive enzymes of the respective species. Extracts prepared with faeces and digestive tissue from $H$. gammarus showed a single phosphatase activity band, which very likely represented the endogenous phosphatase synthesised in the
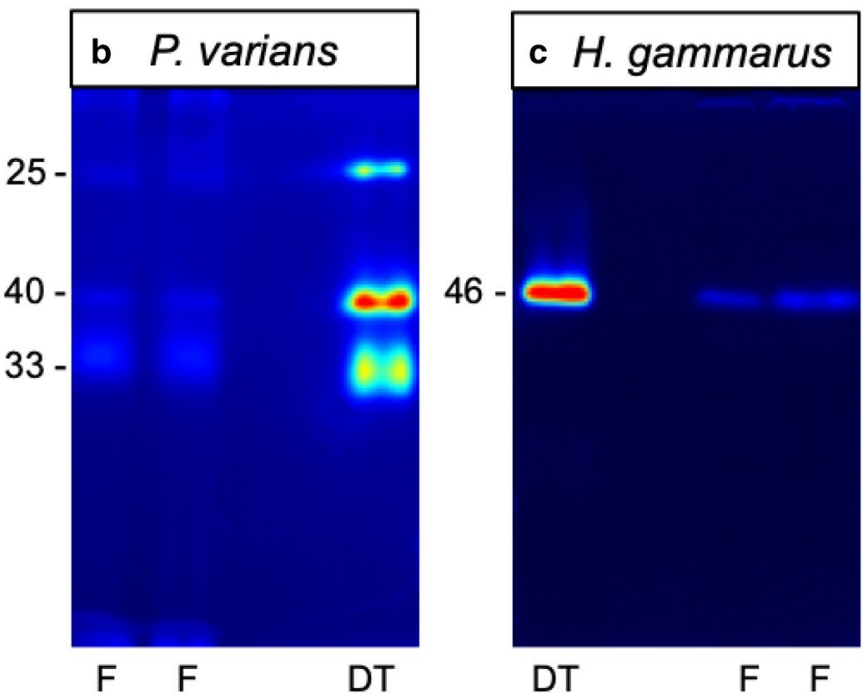
a I. balthica
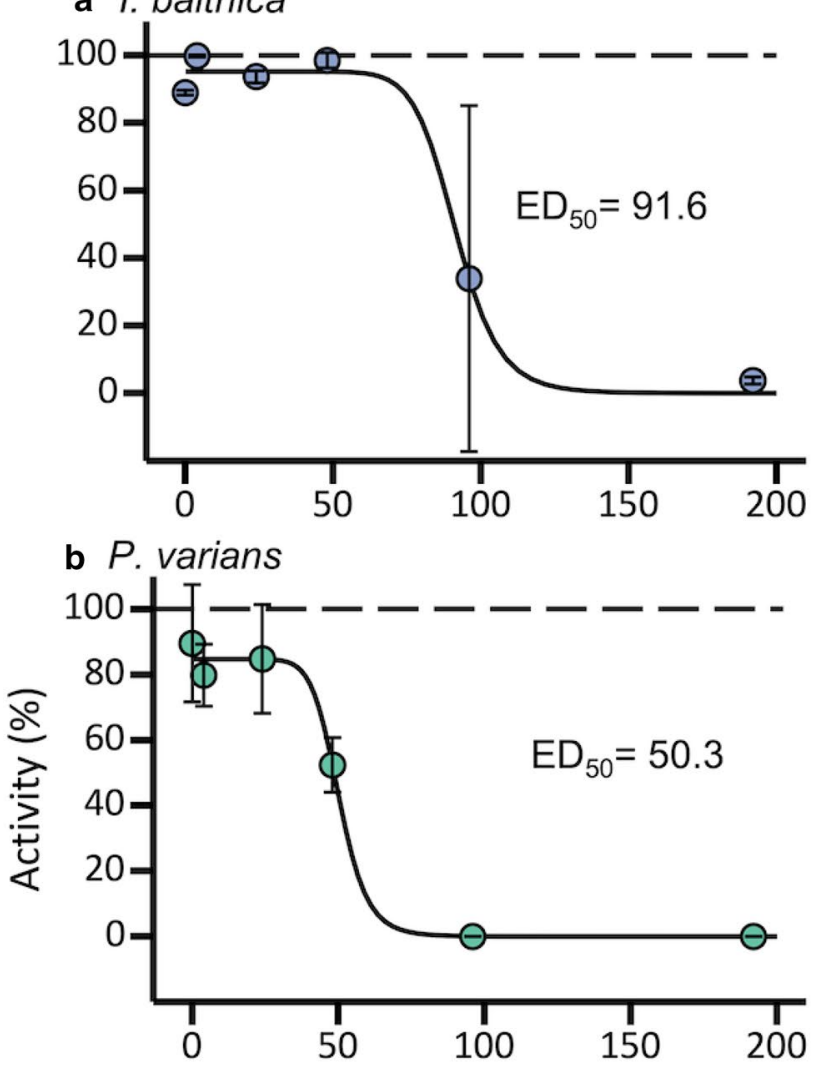

c H. gammarus

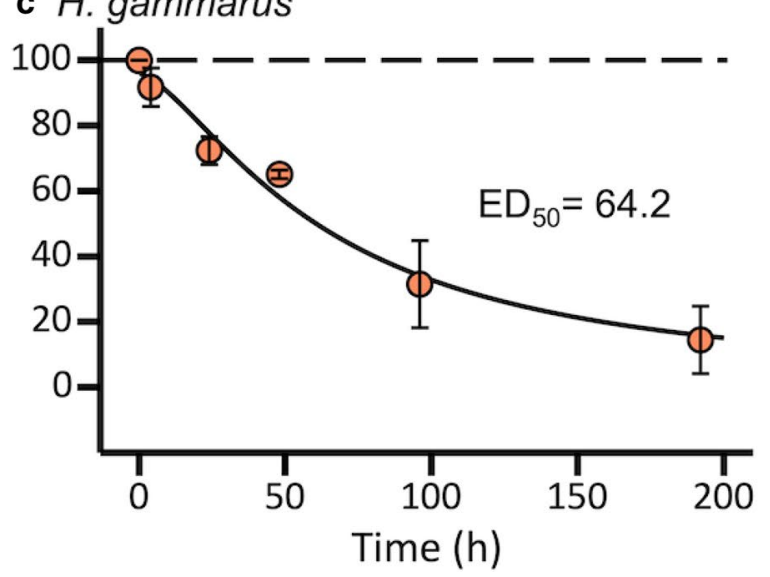

Fig. 4 Stability of phosphatase activity in extracts of faeces of a Idotea balthica, b Palaemon varians, and c Homarus gammarus. Activities measured at six time points are expressed in relation (\%) of maximum activity (100\%) indicated by the dashed lines

digestive tissues. The appearance of multiple phosphatase activity bands in P. varians and I. balthica extracts could represent isoenzymes, which can be expressed under certain dietary conditions (Guérin and Kerambrun 1982). Eguchi et al. (1972) found isoforms of alkaline phosphatase in the silkworm Bombyx mori and Lee and Chuang (1991) found three isoforms of alkaline phosphatase in the shrimp Penaeus monodon, one having a molecular mass of $43 \mathrm{kDa}$
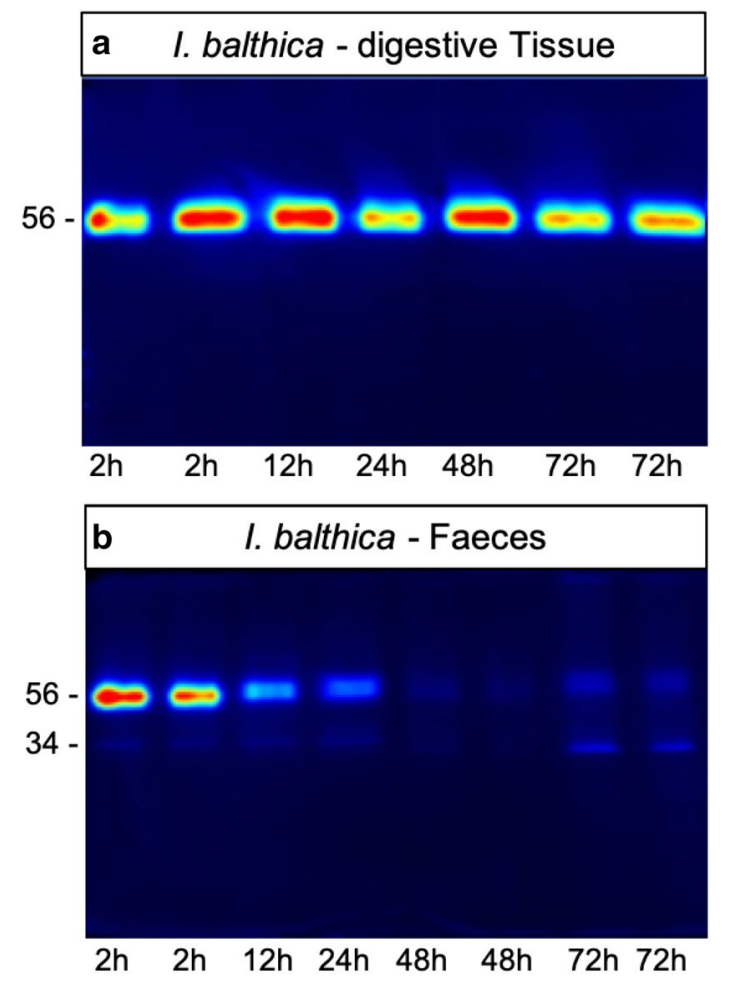

Fig. 5 Zymograms of extracts of a digestive tissue extracts; $\mathbf{b}$ faeces extracts of $I$. balthica stained with MUF-P which were incubated for $2,12,24,48$, and $72 \mathrm{~h}$ at $16{ }^{\circ} \mathrm{C}$ in the dark. The apparent molecular weights (in $\mathrm{kDa}$ ) are indicated on the left side of the panels

and the other two of $31 \mathrm{kDa}$. These molecular masses are similar to those of phosphatases from the shrimp faeces and digestive tissue extracts $(40 \mathrm{kDa}$ and $33 \mathrm{kDa})$. Phosphatases with similar molecular masses were also detected in $\mathrm{H}$. gammarus $(46 \mathrm{kDa})$ and I. balthica $(56 \mathrm{kDa}$ and $34 \mathrm{kDa})$. However, the phosphatase activity band at $34 \mathrm{kDa}$ found in the extracts of I. balthica was also present in an extract from the food $F$. vesiculosus. This band could represent a phosphatase expressed by $F$. vesiculosus, which was still detected in the digestive tract and the faeces of I. balthica, probably due to low assimilation capabilities. Multiple bands of both $I$. balthica and $P$. varians might indicate various isoforms or precursors of enzymes or active fragments as suggested by Vandooren et al. (2013). Alternatively, additional activity bands might also originate from bacteria, which were either attached to the food and ingested, or from commensalic or symbiotic bacteria present in the digestive organs of the crustaceans.

\section{Microbial sources}

Exposure of the animals to the antibiotic/antimycotic mixture showed a significant reduction in phosphatase activity in the faeces of $P$. varians but not in those of I. balthica 
and $H$. gammarus. Using the same substances, Donachie et al. (1995) showed that saprophytic bacteria as well as total bacteria counts strongly decreased in the hepatopancreas and stomach of Northern krill, Meganyctiphanes norvegica, already after $24 \mathrm{~h}$. The authors also found a significant decrease of several digestive enzymes, coinciding with low bacterial numbers. In the present study, a similar incubation time (17-20 h) and antibiotic concentration were used, presumably reducing bacterial numbers as effectively as reported by Donachie et al. (1995). Accordingly, the interpretation of our results, that bacteria may contribute to the phosphatase production in the faeces of $P$. varians but not in I. balthica and H. gammarus appears suitable. However, it has to be considered, that reduction of bacteria numbers may not immediately entail a drop in enzyme activity because the released enzymes may remain stable for several days, as discussed below. Additional long-tern experiments are required to better investigate the bacterial contribution on the phosphatase production of $P$. varians.

Information about the presence and the role of symbiotic bacteria in crustacean is scarce and inconsistent. Bacteria and other microorganisms are permanently ingested with the food and egested again with the faeces. However, it remains to be determined, when bacteria can be considered symbiotic in the narrower sense or just constitute the natural and temporal microbiome. According to Zimmer et al. (2001), semi-terrestrial isopods, Ligilla pallasii, contained high numbers of endosymbionts. Antibiotic treatment reduced bacteria numbers and decreased the digestibility of food. In contrast, the marine species Idotea wosnesenskii and Gnorimosphaeroma oregonensis did not contain bacteria in their hepatopancreas and no decrease in approximate digestibility was observed after antibiotic treatment (Zimmer et al. 2001). Sleeter et al. (1978) discovered that no resident microflora was present in the digestive tract of marine wood boring isopod Limnoria tripunctata. The gut contents as well as faeces of this species were also only sparsely colonised by bacteria. In addition, the results of Guarino et al. (1994) gave no indication for hepatopancreatic bacteria in I. balthica. Mattila et al. (2014) found bacteria in the gut and in the midgut gland of I. balthica, but effects of antimicrobial treatment on the bacteria counts differed with the predominant food source of the isopods.

Antibiotic treatment did not reduce phosphatase activity in samples of H. gammarus and no studies are available which clearly indicate the presence of digestive symbionts (in the narrower sense) in H. gammarus. However, several studies found bacteria in the digestive systems of other marine decapods, among them Nephrops norvegicus (Meziti et al. 2010), which belongs to the same family as $H$. gammarus. The bacterial community in $N$. norvegicus varied with sampling time (season) and is probably related to temporal variation of food (Meziti et al. 2010).

\section{Durability of enzymes}

Our results on enzyme durability (activity measurements and zymograms) are in line with previous studies. Steen and Arnosti (2011) showed that natural free enzymes ( $\beta$-glucosidase and phosphatase) lost very little activity over the course of $36 \mathrm{~h}$. Their measurements were, however, terminated after $36 \mathrm{~h}$. In the present study, phosphatase enzymes had half-lives $\left(\mathrm{ED}_{50}\right)$ of at least $50 \mathrm{~h}$ ( 2 days $)$ and maximum of almost $92 \mathrm{~h}(\sim 4$ days $)$, corresponding to the finding of Steen and Arnosti (2011). The actual durability in the present study could have been even longer because the faeces were egested up to $16 \mathrm{~h}$ prior to collection and processing.

The decrease of phosphatase enzyme activities in the faeces extracts of all investigated species is a considerable argument against significant microbial enzyme production. It can be assumed, that the extracts are rich in various nutrients and, thus, provide suitable conditions for microbial growth, moreover at a fostering temperature of $16^{\circ} \mathrm{C}$. Accordingly, a prospering microbial community should be expected which increase enzyme activity or, at least, maintain it at initial levels. The observed decrease of activities could only then be explained by the collapse of the microbial community, which, in turn, would also undermine concepts of marine microbial growth and activity in marine systems. More likely, the decrease is due to the continuous degradation of phosphatases by proteolytic enzymes or other physicochemical effects.

Faeces extracts may also contain high amounts of proteases, which are capable of hydrolysing phosphatase enzymes and, thus, reducing their lifetime (Steen and Arnosti 2011). Saborowski et al. (2004) measured proteolytic activity in pure gastric fluid of the Edible Crab Cancer pagurus over a longer time span. Chymotrypsin, trypsin and total protease activity were stable for as long as 127 days and, therefore, much longer than the phosphatase of the present study. The stability of these endopeptidases is due to mutations, which reduced the number of autoproteolytic cleavage sites at the surface of the enzyme molecule (Hehemann et al. 2008). The structural resistance of crustacean phosphatase against proteolysis are yet to be investigated. Other factors influencing the stability and activity of exoenzymes may be association with dissolved organic matter (DOM) (Keil and Kirchman 1994), extrapolymeric substances (Huston et al. 2004), or cells or particles (Ziervogel et al. 2007).

\section{Sources of crustacean phosphatases}

Digestion is a complex process in crustaceans (Saborowski 2015). Digestive enzymes are released from the midgut gland (also referred to as hepatopancreas) into the stomach, where they facilitate the initial steps of food utilization. 
The resulting chyme is pressed back into the midgut gland through the pyloric filter, which separates both organs. Nutrients are absorbed in the midgut gland (Loizzi 1971; Vogt 1994). Undigested food mash soaked with remaining gastric fluid including active enzymes is finally excreted with the faecal pellets. Presumably, only a small amount of digestive enzymes is released with the undigested material. Enzyme production is energetically costly. Therefore, it would be adverse for the animal to lose high amounts of these enzymes through egestion (Allison et al. 2010).

The different ratios of activities between faeces and digestive organs among the studied species may indicate differences in the anatomy and/or physiology of the species. Several factors including sex (Strong and Daborn 1979), size and age (Lee and Lawrence 1985), as well as the moulting cycle and starvation during pre-moult (Klein et al. 1996; Muhlia-Almazán and García-Carreño 2002) are known to influence metabolism and might also lead to intraspecific differences of enzyme activities. These factors were not assessed in our study but cannot be excluded. However, animals in the late stages of pre-moult were omitted from enzyme analysis, because they do not feed and, thus, do not produce faecal pellets.

Intraspecific variation of phosphatase activity in the faeces might also be due to leakage of enzymes from the faeces after egestion and exposure to water. The faecal material is enveloped within porous peritrophic membranes (Peters 1992). The leakage of dissolved organic carbon from faeces has been observed within a few hours after egestion (Thor et al. 2003). Faeces were collected every $16 \mathrm{~h}$ in our study. Thus, their maximum age (time after egestion) is defined, but not the real age of each single faecal pellet. Therefore, faeces from some animals might have been exposed to water for a shorter period than others.

Variations between species might be due to the specific physiological properties. Dietary differences, for example, might cause modifications in gut retention time, assimilation efficiency, and digestive enzyme synthesis. Gutow et al. (2006) observed differences in digestive enzyme activities between the mainly herbivorous I. balthica and the more carnivorous I. metallica. Herbivorous species might also have short gut retention times (Kurmaly et al. 1989). Long gut retention times, i.e., low ingestion and egestion rates, can have a positive effect on the assimilation efficiency (Boehlert and Yoklavich 1984). It also has to be noted that the parts of the digestive tract used for extract preparation were not the same for all species. In the case of I. balthica, the midgut gland was used together with the gut because both organs contribute significantly to digestive processes. In the case of $P$. varians and $H$. gammarus, only the midgut glands were used, as they represents the major digestive organs. The guts of these species are tenuous and difficult to dissect. Variation of phosphatase activity in the faeces of different species could be due to the differences in the rate of enzyme leakage. Lobster and shrimp faeces have an elongated tubular shape compared to the almost spherical shape of the isopod faeces. It is possible that enzyme leakage from the faecal pellets of the lobsters and shrimps is higher than from those of isopods due to a higher surface/volume ratio of their faeces.

\section{Ecological implications}

Extracellular enzyme activity has almost exclusively been attributed to bacteria (Hoppe et al. 1988; Chróst 1991; Sala and Güde 1996; Arnosti et al. 2014). Thus, degradation of organic matter by bacteria is considered to be the key process in remineralisation (Azam and Malfatti 2007; Pomeroy et al. 2007). There are, however, indications that remineralisation processes cannot be exclusively explained by bacterial activity (Giering et al. 2014, and references therein). Bochdansky et al. (1995) studied the influence of zooplankton-grazing on the concentration of free dissolved enzymes in the water and found a significant increase in the concentration of free dissolved enzymes whenever zooplankton was present. This increase was attributed to a substantial release of digestive enzymes derived from the zooplankton. Rigler (1961) found little difference between the enzymatic activities in an antibiotic-treated culture of Daphnia magna and an untreated culture of this species, which indicates that active enzymes derived from $D$. magna. Wynne and Gophen (1981) reported that the enzyme activities released by $D$. magna varied according to the food source and suggested that these may either be digestive enzymes released by $D$. magna or components of their food. The latter was ruled out by the study of Boavida and Heath (1984).

The findings of the present study strongly indicate that extracellular enzymes from invertebrate origin can significantly contribute to the extracellular enzyme pool in the marine environment. Jacobsen and Azam (1984) concluded that bacteria colonising faecal pellets may not be the major group responsible for carbon mineralisation in the upper water column. Bacteria have been shown to be scarce on freshly egested faecal pellets, but they colonised a significant part of the pellet surface after $24 \mathrm{~h}$ (bacteria per surface area) (Jacobsen and Azam 1984). Organic matter, however, rapidly leaks from the faecal pellets directly after egestion (Møller et al. 2003). This indicates that bacterial activity cannot be the cause for this organic matter release. Jumars et al. (1989) stated that endogenous digestive enzymes are excreted with faecal pellets and remain active. The released organic matter, or the enzymes themselves, represent a primary nutrient source for bacteria, which helps the bacteria to settle on particles. This process could also initialise the colonisation of these particles by bacteria, assuming the bacteria follow chemical cues in search for food (Vetter et al. 1998; Kiørboe and Jackson 2001). 
In offshore surface waters or shallow coastal waters, the released nutrients, here phosphorus, can be directly utilised by primary producers like phytoplankton or macroalgae. In this way, herbivorous marine animals (e.g., I. balthica) could potentially directly fertilise their own food source (Boavida and Heath 1984). Epibenthic animals like H. gammarus and $P$. varians may contribute directly in fertilising the benthic flora and turnover rates of organic matter in shallow water sediments. The advantage for carnivorous species would be more indirect, but they still benefit if nutrients are instantly provided to primary producers, which form the basis of the food chain.

Our considerations can be easily transferred into the open water, where various pelagic species feed on phytoplankton and zooplankton, thereby releasing immense amounts of faecal pellets. Enzymes which are stable for several days could also, via particle flux, be taken down to deeper waters, potentially adding to the active enzyme pool in the deep sea and further participating in remineralisation processes (Baltar et al. 2010). Stability of cell free and particle-associated extracellular enzymes can have a great impact on the microbial loop and on turnover rates of organic matter in marine systems (Boudreau et al. 2008; Steen and Arnosti 2011). Faecal pellets of zooplankton sink up to $50 \mathrm{~m}$ per day (Urban-Rich 1999). Most enzymes examined in the present study still had activity after 8 days (half-lives were shorter). During this time, these enzymes could reach depths between 400 and $540 \mathrm{~m}$ (mesopelagic realm). The importance of enzymes originating from sinking particles in greater depths has been demonstrated by Koike and Nagata (1997), who suggested that sinking particles, rather than bacteria inhabiting these depths, were the source of alkaline phosphatase activity (APA) in the deep sea. This corresponds with the findings of Davis and Mahaffey (2017), showing that alkaline phosphatase activity was strongly concentrated in fast-sinking particles, which were zooplankton faecal pellets. Slow-sinking particles had low alkaline phosphatase activities and were mostly phytodetritus (from "sloppy feeding"). Phytodetritus probably derived from autotrophic biomass in surface layers. Therefore, it was hypothesised that zooplankton may have contributed to alkaline phosphatase (AP) present in the mid-water layer through the introduction of AP associated with faecal pellets (Davis et al 2019). "Sloppy feeding" contribution to APA was considered less likely because of low APA in slow-sinking phytodetritus. Generally, these findings show that sinking particles, and especially faecal pellets, might be an important source of enzymes and that these enzymes are not necessarily derived from bacteria. The discussed literature, in concert with the results of our study, suggests a strong potential for the contribution of extracellular enzymes of invertebrate origin to marine nutrient cycles. Enzymes released with egesta from animals could initialise the bacterial colonisation of these particles through the release of dissolved organic matter (carbohydrates, amino acids, lipids, etc.) or dissolved inorganic matter, such as dissolved inorganic phosphorus or dissolved inorganic nitrogen. These solutes could act as chemical cues for the bacteria, facilitate bacterial production, and help sustain the microbial population in and on these particles. In this way, egesta would contribute to remineralisation processes and at the same time fuel microbial growth and, consequently microbial remineralisation abilities (Fig. 6). Thus, extracellular enzymes from marine invertebrates (or metazoan in general) would precede and fuel the processes attributed to the microbial loop.

\section{Conclusions}

The results support our first hypothesis, that crustaceans release active phosphatases with their faeces. Antibiotic treatment did not reduce phosphatase activities in the faeces of $I$. balthica and $H$. gammarus but in the faeces of $P$. varians. This may allow for the assumption that enzymes did not derive from bacteria in I. balthica and H. gammarus but partly in $P$. varians. However, a definite conclusion cannot be drawn from the present results but needs further validation. The enzymes were stable for several days, which was shown by the activity time series of all three species and the zymogram time series of I. balthica. Consequently, the hypothesis that crustacean extracellular enzymes of are stable under natural conditions can be accepted. The fact that the enzymes were most active at the beginning of the time series and activity declined with increasing incubation time is a strong indication that numbers of bacteria might have been too low to establish a sustaining population, which produced significant amounts of phosphatase enzymes. This further supports our hypothesis that phosphatases were of endogenous, i.e., crustacean origin, capable of facilitating degradation and remineralisation processes, and potentially boosting microbial growth. 


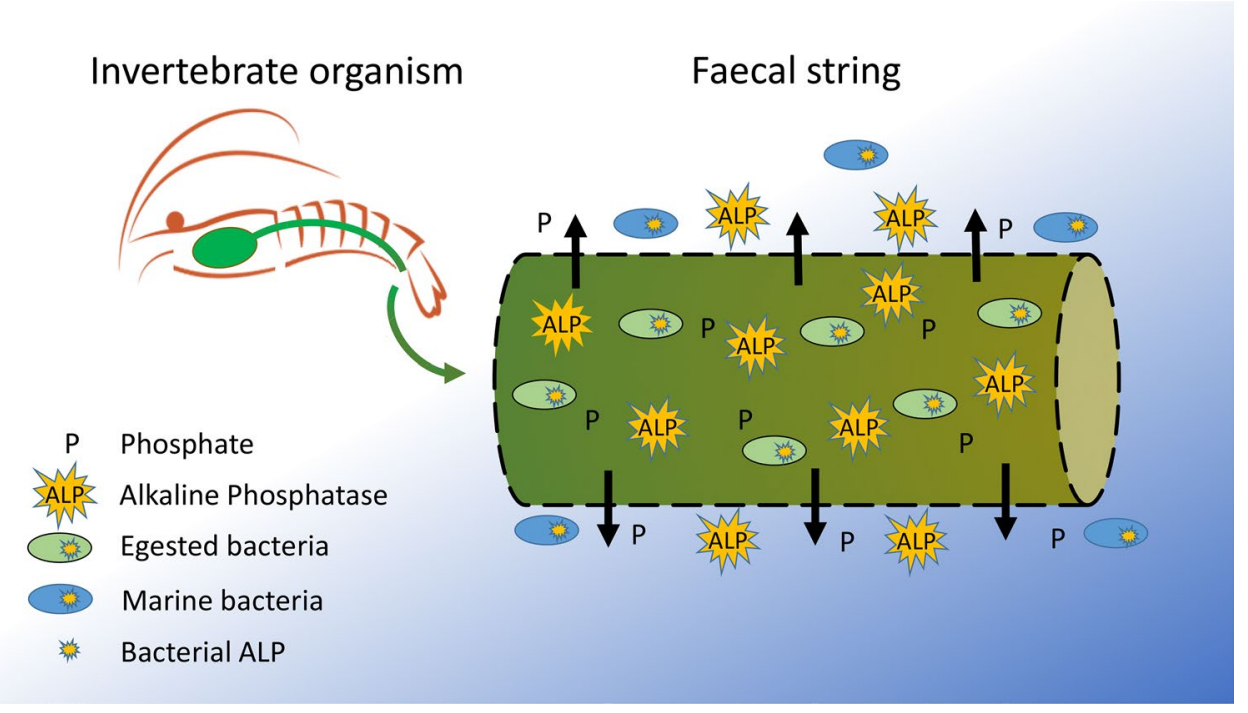

Fig. 6 Conceptual consideration on the generation, liberation, and biological interaction of extracellular phosphatases derived from invertebrate faeces. Animals ingest food (phyto- and zooplankton, macroalgae, etc.) and process it in the stomach and other digestive organs. The food is mixed with highly active digestive enzymes, which initiate the first steps of food digestion and nutrient utilization. Undigested material in the stomach contains remains of enzymes, here endogenous phosphatases, which are egested with the faeces.

Acknowledgements Open Access funding provided by Projekt DEAL. We gratefully acknowledge the technical and laboratory support of Ms Kristine Reuter. This work was carried out within the framework of the PACES II research program of the Helmholtz Association.

Author contributions IMB and RS designed the study. IMB performed the experiments, collected and processed the data. IMB and RS drafted and finalized the manuscript. Both authors read and approved the final version of the manuscript.

Data availability Data collected and analyzed within the current study are available from the corresponding author upon reasonable request.

\section{Compliance with ethical standards}

Conflict of interest The authors declare that they have no conflict of interest.

Ethical approval All international, national, and institutional guidelines for sampling of organisms for this study have been followed.

Open Access This article is licensed under a Creative Commons Attribution 4.0 International License, which permits use, sharing, adaptation, distribution and reproduction in any medium or format, as long as you give appropriate credit to the original author(s) and the source, provide a link to the Creative Commons licence, and indicate if changes were made. The images or other third party material in this article are included in the article's Creative Commons licence, unless indicated otherwise in a credit line to the material. If material is not included in the article's Creative Commons licence and your intended use is not permitted by statutory regulation or exceeds the permitted use, you will
The faeces are coated by a porous peritrophic membrane. It maintains the shape of the pellet but allows diffusion of molecules from the inside into the surrounding water. These molecules can be degraded nutrients as well as still active enzymes. Simultaneously, the pellets will contain bacteria and other microbes which were ingested together with the food. Diffusing nutrients may additionally fuel growth of external marine bacteria which attached at the surface of the faecal pellet

need to obtain permission directly from the copyright holder. To view a copy of this licence, visit http://creativecommons.org/licenses/by/4.0/.

\section{References}

Allison SD, Weintraub MN, Gartner TB, Waldrop MP (2010) Evolutionary-economic principles as regulators of soil enzyme production and ecosystem function. In: Shukla G, Varma A (eds) Soil enzymology. Springer, Berlin, pp 229-243

Arnosti C (2011) Microbial extracellular enzymes and the marine carbon cycle. Annu Rev Mar Sci 3:401-425

Arnosti C, Bell C, Moorhead DL, Sinsabaugh RL, Steen AD, Stromberger M, Wallenstein M, Weintraub MN (2014) Extracellular enzymes in terrestrial, freshwater, and marine environments: perspectives on system variability and common research needs. Biogeochemistry 117:5-21

Azam F, Malfatti F (2007) Microbial structuring of marine ecosystems. Nat Rev Microbiol 5:782-791

Baltar F, Arístegui J, Gasol JM, Sintes E, van Aken HM, Herndl GJ (2010) High dissolved extracellular enzymatic activity in the deep central Atlantic Ocean. Aquat Microb Ecol 58:287-302

Boavida MJ, Heath RT (1984) Are the phosphatases released by Daphnia magna components of its food? Limnol Oceanogr 29:641-645

Bochdansky AB, Puskaric S, Herndl GJ (1995) Influence of zooplankton grazing on free dissolved enzymes in the sea. Mar Ecol Prog Ser 121:53-63

Boehlert GW, Yoklavich MM (1984) Carbon assimilation as a function of ingestion rate in larval pacific herring, Clupea harengus pallasi Valenciennes. J Exp Mar Bio Ecol 79:251-262 
Boudreau BP, Arnosti C, Jørgensen BB, Canfield DE (2008) Comment on "Physical model for the decay and preservation of marine organic carbon". Science 319:1616b

Chróst RJ (1991) Ectoenzymes in aquatic environments: microbial strategy for substrate supply. Verh Internat Verein Limnol 24:2597-2600

Clark LL, Ingall ED, Benner R (1998) Marine phosphorus is selectively remineralized. Nature 393:426

Davis CE, Mahaffey C (2017) Elevated alkaline phosphatase activity in a phosphate- replete environment: influence of sinking particles. Limnol Oceanogr 62:2389-2403

Davis C, Lohan MC, Tuerena R, Cerdan-Garcia E, Woodward EMS, Tagliabue A, Mahaffey C (2019) Diurnal variability in alkaline phosphatase activity and the potential role of zooplankton. Limnol Oceanogr Lett 4:71-78

Donachie SP, Saborowski R, Peters G, Buchholz F (1995) Bacterial digestive enzyme activity in the stomach and hepatopancreas of Meganyctiphanes norvegica (M. Sars, 1857). J Exp Mar Bio Ecol 188:151-165

Dyhrman ST, Ruttenberg KC (2006) Presence and regulation of alkaline phosphatase activity in eukaryotic phytoplankton from the coastal ocean: implications for dissolved organic phosphorus remineralization. Limnol Oceanogr 51:1381-1390

Eguchi M, Sawaki M, Suzuki Y (1972) Multiple forms of midgut alkaline phosphatase in the silkworm: separation and comparison of two isoenzymes. Insect Biochem 2:167-174

Espie PJ, Roff JC (1995) Characterization of chitobiase from Daphnia magna and its relation to chitin flux. Physiol Zool 68:727-748

Föllmi KB (1996) The phosphorus cycle, phosphogenesis and marine phosphate-rich deposits. Earth Sci Rev 40:55-124

Giering SLC, Sanders R, Lampitt RS, Anderson TR, Tamburini C, Boutrif M, Zubkov MV, Marsey CM, Henson SA, Saw K, Cook K, Mayor DJ (2014) Reconciliation of the carbon budget in the ocean's twilight zone. Nature 507:480-483

Guarino SM, Gambardella C, Gragnaniello G, de Nicola M (1994) A preliminary study of hepatopancreas ultrastructure in Idotea balthica (Isopoda). Crustaceana 66:153-162

Guérin J-P, Kerambrun P (1982) Effects of diet on esterases, alkaline phosphatase, malate dehydrogenase and phosphoglucomutase activity observed by polyacrylamide gel electrophoresis in Tisbe holothuriae (harpacticoid copepod). Comp Biochem Physiol Part B Comp Biochem 73:761-770

Gutow L, Strahl J, Wiencke C, Franke H-D, Saborowski R (2006) Behavioural and metabolic adaptations of marine isopods to the rafting life style. Mar Biol 149:821-828

Hargrave BT, Geen GH (1968) Phosphorus excretion by zooplankton. Limnol Oceanogr 13:332-342

Hehemann J-H, Redecke L, Murugaiyan J, von Bergen M, Betzel C, Saborowski R (2008) Autoproteolytic stability of a trypsin from the marine crab Cancer pagurus. Biochem Biophys Res Commun 370:566-571

Hoppe H-G (1983) Significance of exoenzymatic activities in the ecology of brackish water: measurements by means of methylumbelliferyl-substrates. Mar Ecol Prog Ser 11:299-308

Hoppe H-G (1993) Use of fluorogenic model substrates for extracellular enzyme activity (EEA ) measurement of bacteria. In: Kemp PF, Sherr BF, Cole JJ (eds) Current methods in aquatic microbial ecology. CRC Press, Boca Raton, pp 423-431

Hoppe H-G, Kim S-J, Gocke K (1988) Microbial decomposition in aquatic environments: combined process of extracellular enzyme activity and substrate uptake. Appl Environ Microbiol 54:784-790

Hoppe H-G, Arnosti C, Herndl GF (2002) Ecological significance of bacterial enzymes in the marine environment. In: Burns RG, Dick RP (eds) Enzymes in the environment: activity, ecology, and applications. Marcel Dekker Inc., New York, pp 73-107
Huston AL, Methe B, Deming JW (2004) Purification, characterization, and sequencing of an extracellular cold-active aminopeptidase produced by marine psychrophile Colwellia psychrerythraea strain 34H. Appl Environ Microbiol 70:3321-3328

Jacobsen TR, Azam F (1984) Role of bacteria in copepod fecal pellet decomposition: colonization, growth rates and mineralization. Bull Mar Sci 35:495-502

Johannes RE (1964) Uptake and release of dissolved organic phosphorous by representatives of a coastal marine ecosystem. Limnol Oceanogr 9:224-234

Jumars PA, Penry DL, Baross JA, Perry MJ, Frost BW (1989) Closing the microbial loop: dissolved carbon pathway to heterotrophic bacteria from incomplete ingestion, digestion and absorption in animals. Deep Sea Res Part A Oceanogr Res Pap 36:483-495

Karner M, Rassoulzadegan F (1995) Extracellular enzyme activity: indications for high short-term variability in a coastal marine ecosystem. Microb Ecol 30:143-156

Karner M, Ferrier-Pages C, Rassoulzadegan F (1994) Phagotrophic nanoflagellates contribute to occurrence of $\alpha$-glucosidase and aminopeptidase in marine environments. Mar Ecol Prog Ser 114:237-244

Keil RG, Kirchman DL (1994) Abiotic transformation of labile protein to refractory protein in sea water. Mar Chem 45:187-196

Kiørboe T, Jackson GA (2001) Marine snow, organic solute plumes, and optimal chemosensory behaviour of bacteria. Limnol Oceanogr 46:1309-1318

Klein B, Le Moullac G, Sellos D, Van Wormhoudt A (1996) Molecular cloning and sequencing of trypsin cDNAs from Penaeus vannamei (Crustacea, Decapoda): use in assessing gene expression during the moult cycle. Int J Biochem Cell Biol 28(5):551-563

Knotz S, Boersma M, Saborowski R (2006) Microassays for a set of enzymes in individual small marine copepods. Comp Biochem Physiol Part A Mol Integr Physiol 145:406-411

Koike I, Nagata T (1997) High potential activity of extracellular alkaline phosphatase in deep waters of the central Pacific. Deep Sea Res Part II Top Stud Oceanogr 44:2283-2294

Kurmaly K, Yule AB, Jones DA (1989) An energy budget for the larvae of Penaeus monodon (Fabricius). Aquaculture 81:13-25

Lee A-C, Chuang N-N (1991) Characterization of different molecular forms of alkaline phosphatase in the hepatopancreas from the shrimp Penaeus monodon (Crustacea: Decapoda). Comp Biochem Physiol Part B Comp Biochem 99:845-850

Lee PG, Lawrence AL (1985) Effects of diet and size on growth, feed digestibility and digestive enzyme activities of the marine shrimp, Penaeus setiferus Linnaeus. J World Maric Soc 16:275-287

Loizzi RF (1971) Interpretation of crayfish hepatopancreatic function based on fine structural analysis of epithelial cell lines and muscle network. Z Zellforsch 113:420-440

Martinez J, Smith DC, Steward GF, Azam F (1996) Variability in ectohydrolytic enzyme activities of pelagic marine bacteria and its significance for substrate processing in the sea. Aquat Microb Ecol 10:223-230

Mattila JM, Zimmer M, Vesakoski O, Jormalainen V (2014) Habitatspecific gut microbiota of the marine herbivore Idotea balthica (Isopoda). J Exp Mar Biol Ecol 455:22-28

Meziti A, Ramette A, Mente E, Kormas KA (2010) Temporal shifts of the Norway lobster (Nephrops norvegicus) gut bacterial communities. FEMS Microbiol Ecol 74:472-484

Millán JL (2006) Alkaline phosphatases. Structure, substrate specificity and functional relatedness to other members of a large superfamily of enzymes. Purinergic Signal 2:335-341

Møller EF, Thor P, Nielsen TG (2003) Production of DOC by Calanus finmarchicus, C. glacialis and C. hyperboreus through sloppy feeding and leakage from fecal pellets. Mar Ecol Prog Ser 262:185-191 
Muhlia-Almazán A, García-Carreño FL (2002) Influence of molting and starvation on the synthesis of proteolytic enzymes in the midgut gland of the white shrimp Penaeus vannamei. Comp Biochem Physiol Part B 133:383-394

Oosterhuis SS, Baars MA, Klein Breteler WCM (2000) Release of the enzyme chitobiase by the copepod Temora longicornis: characteristics and potential tool for estimating crustacean biomass production in the sea. Mar Ecol Prog Ser 196:195-206

Pantoja S, Lee C (1999) Peptide decomposition by extracellular hydrolysis in coastal seawater and salt marsh sediment. Mar Chem 63:273-291

Paytan A, McLaughlin K (2007) The oceanic phosphorus cycle. Chem Rev 107:563-576

Peters W (1992) Peritrophic membranes. Zoophysiology 30. Springer, Berlin, p 238

Pomeroy LR, Williams PJ, Azam F, Hobbie JE (2007) The microbial loop. Oceanography 20:28-33

Prim N, Sánchez M, Ruiz C, FIJ Pastor, Diaz P (2003) Use of methylumbeliferyl derivative substrates for lipase activity characterization. J Mol Catal B Enzym 22:339-346

Rigler FH (1961) The uptake and release of inorganic phosphorus by Daphnia magna Straus. Limnol Oceanogr 6:165-174

Saborowski R (2015) Nutrition and digestion. In: Chang ES, Thiel M (eds) Natural history of the Crustacea, vol 4. Physiological regulation. Oxford University Press, New York, pp 285-319

Saborowski R, Sahling G, Navarrete del Toro MA, Walter I, GarcíaCarreño FL (2004) Stability and effects of organic solvents on endopeptidases from the gastric fluid of the marine crab Cancer pagurus. J Mol Catal B Enzym 30:109-118

Sala MM, Güde H (1996) Influence of algae and crustacean zooplankton on patterns of microbial hydrolytic enzyme activities - an experimental approach. Arch Hydrobiol Spec Issues 48:143-154

Sleeter TD, Boyle PJ, Cundell AM, Mitchell R (1978) Relationships between marine microorganisms and the wood-boring isopod Limnoria tripunctata. Mar Biol 45:329-336

Steen AD, Arnosti C (2011) Long lifetimes of $\beta$-glucosidase, leucine aminopeptidase, and phosphatase in Arctic seawater. Mar Chem 123:127-132

Štrojsová A, Vrba J, Nedoma J, Komárková J, Znachor P (2003) Seasonal study of extracellular phosphatase expression in the phytoplankton of a eutrophic reservoir. Eur J Phycol 38:295-306
Strong KW, Daborn GR (1979) Growth and energy utilisation of the intertidal isopod Idotea baltica (Pallas) (Crustacea: Isopoda). J Exp Mar Biol Ecol 41:101-123

Suzumura M, Hashihama F, Yamada N, Kinouchi S (2012) Dissolved phosphorus pools and alkaline phosphatase activity in the euphotic zone of the western North Pacific Ocean. Front Microbiol 3:99

Thor P, Dam HG, Rogers DR (2003) Fate of organic carbon released from decomposing copepod fecal pellets in relation to bacterial production and ectoenzymatic activity. Aquat Microb Ecol $33: 279-288$

Urban-Rich J (1999) Release of dissolved organic carbon from copepod fecal pellets in the Greenland Sea. J Exp Mar Biol Ecol 232:107-124

Vandooren J, Geurts N, Martens E, Van den Steen PE, Opdenakker G (2013) Zymography methods for visualizing hydrolytic enzymes. Nat Methods 10:211-220

Vetter YA, Deming JW, Jumars PA, Krieger-Brockett BB (1998) A predictive model of bacterial foraging by means of freely released extracellular enzymes. Microb Ecol 36:75-92

Vogt G (1994) Life-cycle and functional cytology of the hepatopancreatic cells of Astacus astacus (Crustacea, Decapoda). Zoomorphology 114:83-101

White A, Dyhrman S (2013) The marine phosphorus cycle. Front Microbiol 4:105

Wynne D, Gophen M (1981) Phosphatase activity in freshwater zooplankton. Oikos 37:369-376

Ziervogel K, Karlsson E, Arnosti C (2007) Surface associations of enzymes and of organic matter: consequences for hydrolytic activity and organic matter remineralization in marine systems. Mar Chem 104:241-252

Zimmer M, Danko JP, Pennings SC, Danford AR, Ziegler A, Uglow RF, Carefoot TH (2001) Hepatopancreatic endosymbionts in coastal isopods (Crustacea: Isopoda), and their contribution to digestion. Mar Biol 138:955-963

Publisher's Note Springer Nature remains neutral with regard to jurisdictional claims in published maps and institutional affiliations. 